\title{
"THE APPRECIATION OF THE INNOVATIVE WAYANG WONG PERFORMING ARTS THROUGH DIGITAL MEDIA"
}

\author{
Ni Made Ruastiti, I Komang Sudirga, I Gede Yudarta \\ Faculty of Arts, Institute of Indonesia Art Denpasar Email : maderuastiti@isi-dps.ac,id
}

\begin{abstract}
:
The paper aims to analyze the appreciation of Innovative Wayang Wong performing arts.

It is interesting to know because the Innovative Wayang Wong performing arts through digital media is appreciated by Bali's millennial generation. The primary data obtained through observation and interviews with representatives of the Wayang Wong and Wayang Wong 'Cupu Manik Astagina' audience in Denpasar. The data analysis was carried out in qualitative manner. The results show that: (1) The innovative Wayang Wong performance art through digital media is staged by presenting a new Wayang Wong model equipped with advanced technology for the preservation of Balinese culture, the promotion of entertaining and educational culture; (2). The innovative Wayang Wong performance through digital media received a positive response especially Balinese teenagers from the millennial generation. Although audience cannot enjoy Wayang Wong performances directly, they can enjoy them through digital channels.
\end{abstract}

Keywords:

Appreciation, Innovative Wayang Wong, Digital Media.

Article Received: 18 October 2020, Revised: 3 November 2020, Accepted: 24 December 2020

\section{INTRODUCTION}

Culture is a source of identity, heritage and power for humans in their civilization (Muhammad et al., 2020). Art is a cultural element that is needed in constructing, growing a whole human being (Dharmika and Pradana, 2020; Pradana, 2012; Pradana, 2017a; Pradana, 2018; Pradana, 2018a; Ruastiti et.al., 2018; Swandi et.al., 2020; Pradana and Pratiwi, 2020; Pradana and Pratiwi, 2021; Pradana, 2020). As stated in the great outlines of the country direction (GBHN), national development aims to shape the Indonesian ultimately. A healthy human being mentally, physically and physically-spiritually. Whole Indonesian human development is a process that involves the growth of human intelligence and mentality who has a good attitude and personality, as well as a spirituality or spirit. Whole Indonesian human cultivation is the development that humans who have good personality, attitudes, mentality, souls or spiritualities and pursues intelligence.

The effort to cultivate the spirit is more important than merely cultivating the IQ as outlined in the Indonesian national anthem "wake up the soul, build up the body". So, the personality, attitude and mentality with their EQ or SQ must be cultivate first, not IQ as the intelligence of the mind. Art is an aspect that is directly related to the cultivate of the cultural and human spirit (Arniati et al., 2020). So, it is vital if the archipelago continues to cultivate culture by exploring the local wisdom it has to support human progress as a whole (Atmaja et.al., 2019; Dharmika et.al., 2020; Ruastiti, 2020c; Pradana and Parwati, 2017; Pradana and Pratiwi, 2020).

Culture is a source of social satisfaction (Tejayadi et al., 2019). Culture is a factor that positively affects the level of loyalty of many people to a destination (Zhang and Walsh, 2020). Arts in cultural are instruments to harmonize all aspects of life in society and nation (Rai S. et al., 2019). For the people of Indonesian, art and culture are also become a part of Bhineka Tunggal I $k a$ pillars in developing a national personality. The values that need to display in the Indonesia next generation. The Indonesia next generation 
especially millennial generation are the needs of the current 4.0 industrial revolution. Besides being marked by digitalization, millennial generation is required to be able to communicate, creatively, innovatively, think critically and collaborate in all fields. The Indonesian generation especially the millennials needs to have competitive advantage in their life (Ruastiti et al., 2020; Ruastiti, 2020a). They also have good behavior, improve selfcompetence and skills for the global demands (BKSTI, 2017).

Global demands can be defined as Global needs and trends that can become new problems or opportunities for everyone after the world has become globalized in the high frequency of international connections (Robertson, 1992). The international connections that accommodate the economy, society, politics and culture are spread simultaneously throughout the world (Barker, 2005). People find distinctive features and tend to compete as part of their identity (Pradana et.al., 2016; Pradana, 2018b). However, the various stimuli of sophisticated media that mediate global cultural trends have actually resulted in a cultural identity crisis and added paradoxes in their dynamics of their civilization progress (Nasseri et al., 2020). In globalized world, local cultural arts have an excellent opportunity to develop as an ethnic identity (Ruastiti et al., 2020b; Pradana and Pratiwi, 2020; Pradana and Parwati, 2017).

The horizons about cultural ethnicity are not only needed in plurality relations but are needed in the readiness to make good crosscultural and multicultural relations (Fang et al., 2020). The Indonesian next generation must be smart and ready to compete globally. The Indonesian next generation must take an active role, become an actors or agents according to their respective interests and talents, including participating in their art and culture process.

The position of art in cultural is indeed essential to strengthening the Indonesian nation (Ruastiti, 2019). However, traditional arts especially Wayang Wong in Bali are threatened with extinction. Only in a few places in Bali this performing art is preserved. It could be found in Tonja Village Denpasar, Tanjung Benoa Village Badung, Tunjuk Village Tabanan, Anturan Village Buleleng and Tejakula Village Buleleng. For this reason, it is necessary to make efforts to save local geniuses from their ancestral heritage, such as by making art innovations (Ruastiti, 2019a). It is important to think about it considering Wayang Wong as one of the traditional arts in Bali which is experiencing a crisis amid the advancement of it's civilization.

The existence of Wayang Wong is being tested with global culture. Wayang Wong is only familiar among a few senior artists and Balinese leaders amidst the arts revolution and culture industry in the development of world civilization. In the fast development of world civilization, foreign cultures that present digital media colors in music, films and online games on digital networks tend to be favored by millennials. Balinese youth tend to drift into heavy consumers of various arts available in the digital media. However, to not be isolated or slumped in a foreign culture, all children must be introduced to their ancestors' regional culture. Efforts to explore and revive local culture are significant by the Law Number 5 of 2017 concerning the advancement of culture to maintain national culture as the Indonesian nation's identity. In order to knit, developing and strengthening regional culture and national culture is very necessary.

In connection with the increasingly threatened existence of Wayang Wong on the one hand as well as the need for the diversification of Wayang Wong according to the digital era on the other, the research team from the Indonesian Art Institute (ISI) Denpasar collaborated with Sanggar Paripurna Gianyar to create a New Wayang Wong Performing Art 'Cupu Manik Astagina'. This innovative Wayang Wong is deliberately designed in a new form for preservation of Balinese Wayang Wong performance and created with millennial needs. The performance was designed to involve 120 dancers from kindergarten to high school students as millennial representatives and 
accommodate their active roles as artists in the Balinese Wayang Wong performance stage.

The Innovative Wayang Wong is part of an effort to an effort to inherit the art in cultural of the Balinese Hindu people to the next generation. The packaging for innovative Wayang Wong has received a positive response from the Balinese Wayang Wong performing arts lovers. However, since the beginning of 2020 in the Covid-19 pandemic, fans of the Wayang Wong cannot enyoy it live. But, They can watch it through digital media, namely TV channels and Youtube. There are several new Wayang Wong shows that have been uploaded on Youtube media. Among them, the Innovative Balinese Wayang Wong 'Cupu Manik Astagina' in three locations, namely at Bentara Budaya, Gianyar, on Sanur arts and culture festival during the 2019.

In the current revolution dynamics of industrial 4.0, cultural arts must progress according to great digital technologies. Apart from being a tool in the appreciation of cultural arts, digital technology progress could also use to document works, use as a place for socialization and marketing art it self on a global scale (Ruastiti, 2020b). In connection with the Innovative Balinese performance of Wayang Wong through digital media, this scientific paper discusses : (1) Why is Wayang Wong performed innovatively through digital media ?; (2) How did the audience respond to the innovative Wayang Wong via Youtube?.

\section{LITERATURE REVIEW}

There are some previous studies related to Wayang Wong. The research concerns about the existence of Wayang Wong. Yasasusastra (2011) argues that Wayang Wong is a type of Wayang that presents a lakon by many dancers. They can dance because all movements must follow the main principles of Wayang Wong performance rules.

The existence of Wayang Wong was studied by Soedarsono (1990). He explained, Wayang Wong is a type of traditional theater, a combination of drama arts that developed in the West, Wayang performances that grew and developed in Java. The type of art initially developed primarily in the court environment and among Javanese aristocrats (priyayi), Wayang Wong uses it as a spectacle that was commercialize. The emergence of Wayang Wong groups such as Wayang Wong Sriwedari, Wayang Wong Bharata (Jakarta), Wayang Wong Ngesti Pandawa (Semarang), Wayang Wong Sri Wahito (Yogyakarta) and Wayang Wong RRI Surakarta.

The existence of Wayang Wong continues to progress. In this regard, Wirawan Paneli (2017) discusses transforming the Wayang Wong at the Mustika Yuastina Surabaya Graha Seni Community. He concluded that the Mustika Yuastiana Surabaya Graha Seni Community's existence was an effort to increase public appreciation of the new Wayang Wong. The performance is adapted to many discovery and could be accepted by audience without abandoning traditional values by perfecting : (a) the quality of traditional dance, especially the Surakata dance, (b) dialogue training, and (c) tembang practice. The regeneration process of dancers at the Mustika Yuastina Surabaya Graha Seni Community aims to preserve Wayang Wong by the times.

To support it's existence, Wayang Wong has the potential to be developed as a tourist attraction. In this connection, Ruastiti (2010) explains, Balinese people have developed their arts as a tourist attraction. The Innovative of Balinese Wayang Wong as a tourist attraction has received a positive response from tourists.

Some of the research results generally describe the existence of Wayang Wong. Based on the results, it have not yet reviewed the Innovative performance of Wayang Wong through digital media. However, some of the literature review results use as inspiration and initial knowledge in compiling publications about Balinese Wayang Wong, which are broadcast through TV shows and Youtube. 


\section{MATERIAL AND METHODS}

The paper is the result of qualitative research. The object of research includes the main material of the research in the Innovative Wayang Wong performance 'Cири Manik Astagina' which was initiated by a research team from the Indonesian Art Institute (ISI) Denpasar in collaboration with the Puripurna studio, Gianyar. The determination of the object of the research based on the reasons : (a) the Balinese Wayang Wong is increasingly rare in globalized, but still exists in Denpasar, Badung,
Tabanan and Buleleng; (b) Wayang Wong can be used as a vehicle for talents and character building of the next generation especially millennial generation; (c) the need to conserve and progress of Wayang Wong according to digital trends in revolution industrial (4.0). All data were collected through document study, observation of Wayang Wong, and in-depth interviews with informants from puppet art lovers, puppet art observers and puppet art actors in Denpasar and Gianyar as shown in the picture below.

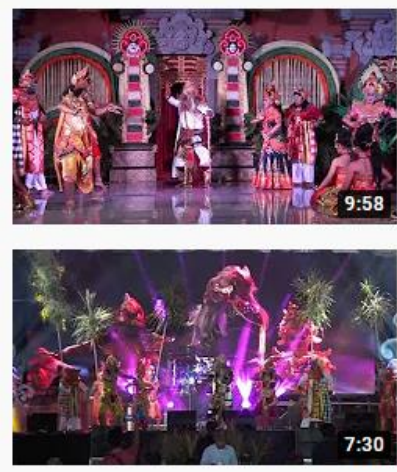

Wayang Wong Milenial Cupu Manik Astagina Pura Dalem Bona Made Ruastiti $\cdot 100$ views $\cdot 10$ months ago

05 Agustus 2019 Program Kementrian Ristekditi ISI Denpasar Bekeriasama dengan Sanggar Tari Paripurna Berlokasi Di Bantara ..

Wayang Wong Milenial Cupu Manik Astagina Sanur

Made Ruastiti $\cdot 81$ views $\cdot 10$ months ago

21 Agustus 2019 Program Kementrian Ristekditi ISI Denpasar Bekerjasama dengan Sanggar Tari Paripurna Berlokasi Di Bantara .

Figure 1: Wayang Wong

Millennial on Youtube Channel

(Source:

https://www.youtube.com/results?search_query= wayang+wong+milenial+ruastiti)

Intepretative and descriptive analyzes carried out using symbol and Bourdeau's theory of action. It hoped, this research results could enrich the repertoire of academic research related to the digitization of Balinese Wayang Wong and Indonesia's cultural heritage.

\section{DIGITALIZATION OF BALINESE WAYANG WONG}

Dealing with the stress of thinking in adapting to the process of cultural progress is a way to achieve a better level of well-being (Selian et al., 2020). The

advancement of the human mindset has succeeded in making technological developments so rapidly. In the last decade, humans have enjoyed many benefits brought from technological innovations including making human activities more accessible, faster and simple. Every new technology through innovations always promises positive benefits in change, convenience, speed, increased productivity, progress and popularity (Martono, 2012). The positive benefits of technological developments have even been felt in various life fields, starting from the social, economic, political, and cultural fields (Ruastiti, 2005; Ruastiti, 2010).

The industrial revolution 4.0 among others is marked by digitalization, which is a combination of the manufacturing and internet devices. The process that occurs in cultural and social changes that occur quickly, community's basic needs and the concerning the social wants. The basis for change is the fulfillment of desires 
to fulfill human needs quickly with quality. Therefore in the progress Industrial, many have changed the way humans work from manual use to digitalization or automation (BKSTI 2017).

As the existance of the Balinese Wayang Wong, they must follow the 4.0 trends and demands. There are three fundamental things in the development of Balinese Wayang Wong, including the need for packaging for a new model of Wayang Wong 'Cupu Manik Astagina', cuttingedge IT applications and the existence of Innovative Wayang Wong cultural missions.

First, the innovative Wayang Wong including : (1) the story chosen, namely Cирu Manik Astagina which depicts the life of Resi Ghotama's family in Pasraman; (2) The storyline uses an artistic LCD light background including visualizing scenes in parks, hermitage, and forest. The background includes a stage setting with accessories for trees, flowers and butterflies in the garden and others; (3) The characterizations main characters from the Arya Bang and Arya Kuning both of whom revolution into Subali and Sugriwa as monster monkey figures; (4) Innovative costumes : monkey (wenara) and others; (5) The Innovative Wayang Wong discourse uses dialogue in three languages (Balinese, Indonesian, English); (6) Balinese Wayang Wong traditional gamelan combined with bass and keyboard from modern music compositions; (7) Various dance movements and choreography designed to suit the millennial generation who is dynamic, dismonotonous and agile (Ruastiti, 2019).

Second, the application of cutting-edge technology to support Innovative Wayang Wong such as dry ice, sound system, LEDs and lighting laser terchnology to optimize the attraction stage setting. The innovative technology is also applied for packaging the products of broadcasts in videos played on TV channels, Youtube and CDs. The digital device and electronic applications are part of the demands of the Industrial Revolution 4.0. The ability to adapt and transform are an essential factor that an artist must-have. The communication technology in industrial revolution places information at the core of creative process every aspect that artists have practiced (Budiman, 2019).

Digital-based mass media partners are essential in the art industrial revolution 4.0. Publication have become more accessible and extensive. Efforts to package virtual art in the Youtube are part of enjoying digital artworks. Artwork material is converted into digital data that can penetrate space and enjoying it. Anyone can enjoy art virtually without being limited by time and space. It hoped that, the Innovative of Balinese Wayang Wong through TV and Youtube, millennials could get to know and like the cultural traditions as a legacy of their ancestors.

Third, Innovative Balinese Wayang Wong has it's mission. Apart from saving the endangered Balinese performing arts, the new model of Balinese Wayang Wong is also an effort to pass the culture on to future generations. It is crucial because Balinese Wayang Wong contains important Balinese values of Hindu, which are essential to next generations as the future successor.

As part of the arts and culture, the Innovative Balinese Wayang Wong is also an effective medium to preserve the identity and Indonesian nation's personality. The refinement of the Indonesian people's mind and personality can indeed be honed through Balinese art. In this regard, the Prof. Ida Bagus Mantra stated that Balinese people must build their personality through culture, especially arts. Progress orientation means evolution the people's economy but at the same time, it is interpreted to strengthen culture and religious life with arts. Arts in culture are not art in a narrow sense but aesthetics that encourages humans to be creative, dynamic in their attitude to sharpen their institution and achive inner satisfaction (Pradana and Pantiyasa, 2018). Dynamic in attitude to foster creativity. Humans can be respected and progress if they have the great creativity (Mantra, 1996).

Apart from being a vehicle for building personality, art in culture also functions as a 
cultural characteristic and identity for the people, who support the culture concerned. Local culture as an identity in the broader scope is an aspect that distinguishes a nation from another nation. It becomes a differentiator or national identity, which forms a harmony when it is aligned with other nations (Jaeni, 2012).

Millennial generation must have spirit sharpened and talents by including them as subjects, who carry on their ancestors' artistic and cultural. They become subjects are directly involved in creating and appreciating art and culture, including being artists in performances art. Being a artists in Balinese arts-cultural activities means cultivate the mentality of the next generation. According to Schaefer (2003), participating in groups has several benefits :

1. Increase expectations

2. Sharing information

3. Helping each other

4. Facilitating the community

5. Improve social skills

6. As a relational skill model

7. Forming emotional support and catharsis

8. Forming a sense of belonging

9. Correcting errors in family function

10. Reduce the altruism side

11. Build a more meaningful and purposeful life environment

The rapid flow of information in the current of global digitalization demands that every individual of millennial generation in Indonesia must immediately adapt to the progress of the digital tool inventions. As digital natives in the dynamics of global cultural trends, the millennial generation should be more insight and have more access of digital technology than the previous generation. Therefore, so many tasks that involve adaptation to new media need the support the power of the millennial generation. Millennial generation's skills can be recorded in all colleges or universities in Indonesia. The millennial generation is seen as having a influential and central role in every process of advancing Indonesia's assets in the future. Consecuently, they need to prepare themselves to become a future superior generation like have soft skills and hard skills for equal and competitive to other developed nations. In this regard, the innovative Wayang Wong presented in digital media (Youtube) can be used as an effective vehicle in cultivate of the millennial generation's character, talents and work ethic.

The progress of the nation's character for the future generation in the current 4.0 flows includes smart thinking, initiative, caring exercise so that individuals who have healthy characters are authoritarian, sympathy, integrity, intelligent, independent, nationalist and religious (Ristekdikti, 2018; Mulyana, 2004). There are six groups of talent units offered to the millennial generation : electronics, mechanics, civil engineering, sports, agriculture, arts and culture (Ruastiti, 2020b).

\section{AUDIENCES'RESPONSE TO WAYANG WONG 'CUPU MANIK ASTAGINA'}

The creation of the new model of Wayang Wong 'Cupu Manik Astagina' is part of an effort to care for the Balinese Hindu so that global culture do not erode them. In the current of globalization flow, local culture actually could rise to national colour culture, even global culture (Luan and Lee, 2020). Local traditions and arts could have great opportunities as forming a new cultural identity (Collier, 1994). Since being charged in 2019, the Innovative of Wayang Wong 'Cupu Manik Astagina' has proven to have received a positive response from the Balinese people. It's reflected in several Wayang Wong 'Cupu Manik Astagina' performances during 2019

1. The Wayang Wong 'Cupu Manik Astagina' received an enthusiastic welcome from the $\mathrm{V}$ National Pasraman Jamboree participants at Aston Hotel, Denpasar (July 2019).

2. The warm welcome of the indigenous people in Bali to the Wayang Wong 'Cupu 
Manik Astagina' at Pura Dalem Bona, Gianyar (August 2019).

3. A warm welcome from the tourists and tourism people to the Wayang Wong 'Cupu Manik Astagina' at the Sanur arts and culture festival moment (22 August 2019).

4. The Wayang Wong 'Cupu Manik Astagina' in front of the academic people at Bentara Budaya Bali (24 September 2019).

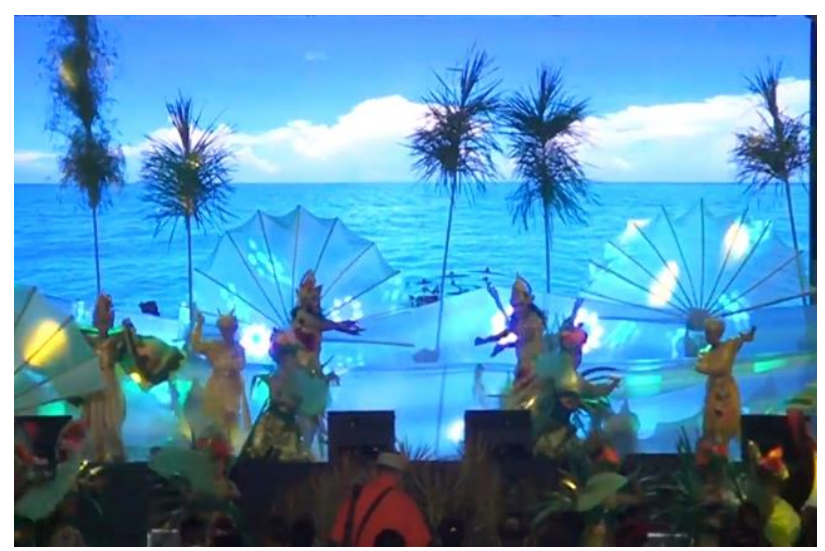

Figure 2 : Wayang Wong 'Cupu Manik Astagina' at Sanur Art and Cultural Festival

(Source : Ruastiti, 2019)

It seemed that youth welcomed the Balinese innovative Wayang Wong arts model. The general public and parents of the new artists appreciated the new arts model in the innovative Balinese Wayang Wong. The audience from various circles also positively welcomed the Wayang Wong's 'Cupu Manik Astagina' potential being developed as a tourist attraction in Bali (Ruastiti, 2020a; Ruastiti, 2020b).

Wayang Wong is an art of the culture of Indonesian. The cultural and sustainability practices containing philosophy values and historical of life (Pradana, 2017). It reflect the nature of human behavior, so it is advantageous as a means of entertaintment, education and information. Wayang Wong has become an eponymous art, which is a beautiful art contains the values of life's virtues and essential as provisions for the next generation (Solichin,
2013).

According to Bourdieu's social action theory (1990), digital technology's sophistication in the current of 4.0 is an asset that the millennial generation needs to awesome master. They will be victorious, smart keep up with the times, and be ready to compete in the global platforms if they are master in the science colored by digital technology.

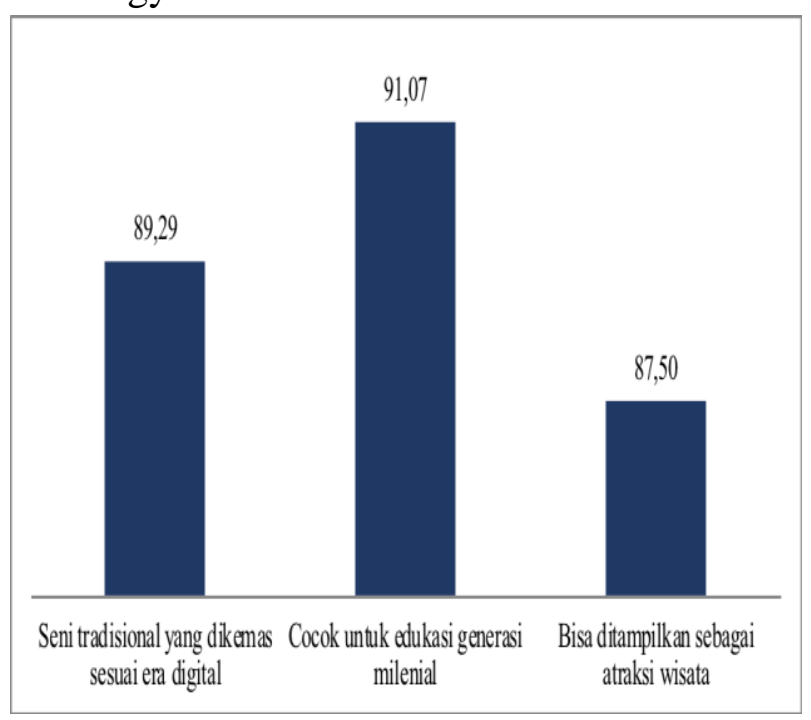

Figure 3

Response of Innovative Wayang Wong audience $(\mathrm{N}=56)$

(Source: Ruastiti, 2020)

Figure 4 shows the audience's response to the Wayang Wong 'Cupu Manik Astagina' performance $(\mathrm{N}=56)$. Respondents considered that Wayang Wong 'Cupu Manik Astagina' is a innovative Balinese art that is suitable for packaging with digital technology $(89,29 \%)$ as educational material for the millennial generation $(91,07 \%)$ and can be displayed as a tourist attraction (87,50\%). Among the educational values of the Innovative Wayang Wong 'Cupu Manik Astagina' are lessons of manners in the family, the need for technological literacy in the tread on the future life and competition in living life. Besides, the Innovative Wayang Wong 'Cupu Manik Astagina' can be commodified : designed in such a way, produced and distributed to consumers as a spectacle according to market demands. 
The commodification is a necessity to ensure the existence, discovery, and continuity of the of Wayang Wong in Bali. The innovative Wayang Wong 'Cupu Manik Astagina' has the potential to be a tourist attraction. Tourist attractions can be understood as tourist destinations and tourist sight in traveling (Pradana, 2019). The new components of Balinese performing arts could be tourist attention (Ruastiti, 2010). Innovative Wayang Wong 'Cupu Manik Astagina' can continue to be developed as an alternative to attractive tourist attractions accepted by tourists. In addition to the audience's response to the Innovative Wayang Wong (Figure 4), there is also a response from the audience to some Wayang Wong shows in digital media packaging (Youtube).

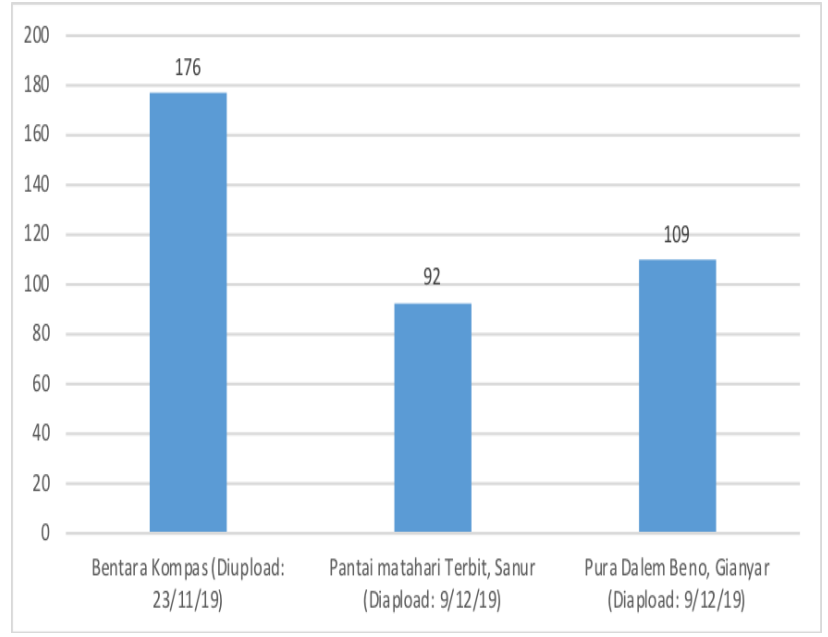

Figure 4

The response of the audience for the Wayang Wong Millennial

(Source : Ruastiti, 2020)

Figure 5 shows the audience's response of the Wayang Wong 'Cupu Manik Astagina' in three locations via Youtube. Until October 14, 2020, the Balinese innovative Wayang Wong which carried the story of Cupu Manik Astagina in three locations, namely (1) on Bentara Budaya Bali on November 23, 2019, was watched by 176 people; (2) at Matahari Terbit Beach, Sanur which on December 9, 2019, watched by 92 people, and (3) at Pura Dalem Bona, Gianyar on December 9, 2019, watched by 109 people. It shows that some Balinese love Wayang Wong Performing Arts. They enjoyed the Innovative Wayang Wong 'Cupu Manik Astagina' shows through the Youtube channel. The acceptance of the Innovative Wayang Wong 'Cupu Manik Astagina' performing arts will automatically support the sustainability of the Balinese Wayang Wong.

\section{CONCLUSION}

Based on this description, it can be concluded that the appreciation of Innovative Wayang Wong 'Cupu Manik Astagina' through digital media is by the needs in the digital movements. In this regard, there are at least three basic things :

1. Packaging a new model for the Wayang Wong 'Cupu Manik Astagina', covering aspects of the story, setting, characterization, innovative costumes and supporting gamelan.

2. Applying the latest technology both to support the Wayang Wong 'Cupu Manik Astagina' as well as for it's packaging and broadcasting through $\mathrm{CD}, \mathrm{TV}$ channels, and Youtube.

3. The presence of the Innovative Wayang Wong 'Cupu Manik Astagina' has cultural mission as a vehicle to strengthen the local cultural identity of the Balinese Hindu people and as a vehicle for the formation of millennial personality and talents.

The Innovative Wayang Wong 'Cupu Manik Astagina' though digital media received a positive response from the audience. The audience considers that :

1. The new Wayang Wong 'Cupu Manik Astagina' is a Balinese art that is suitable for packaging with digital technology.

2. The innovative Wayang Wong 'Cupu Manik Astagina' though digital media as educational material for the millennial generation.

3. The innovative Wayang Wong 'Cupu Manik Astagina' can be presented as a Balinese tourist attraction. 
Although the audience cannot enjoy the series of new Wayang Wong 'Cupu Manik Astagina' show directly, they can enjoy it through digital channels (TV and Youtube).

\section{SUGESSTION}

The new Wayang Wong through digital media channels should be more innovative so that the aspirants of Wayang Wong Performing Arts can enjoy it without being limited by time and space.

\section{ACKNOWLEDGEMENT}

Special thanks are given to Ristekbrin as a research partner of the Innovative Wayang Wong 'Cupu Manik Astagina'.

\section{REFERENCES}

[1] Adorno, T.W. \& Horkheimer, M. (2002). Dialectic of Enlightenment. California: Stanford University Press.

[2] Ardika, I Wayan. (2004). "Pariwisata Bali: Membangun Pariwisata Budaya dan Mengendalikan Budaya Pariwisata" dalam Bali Menuju Jagadhita, Aneka Persepktif. Denpasar: Pustaka Bali Post.

[3] Arniati, Ida Ayu Komang, Gede Marhaendra Wija Atmaja, Gede Yoga Kharisma Pradana. (2020). Moral and Religious Values in The Geguritan Dharma Prawerti Song in Bali. International Journal of Innovation, Creativity and Change, Vol 12(1): pp.432-446.

[4] Atmaja, Gede Marhaendra Wija, Ida Ayu Komang Arniati, Gede Yoga Kharisma Pradana. (2019). Implications of The Enacment of Law Number 6 of 2014 on The Position of Villages in Bali, Indonesia. Asia Life Sciences, Vol. 28, no. 2, pp. 295310.

[5] Barker, Chris. (2005). Cultural Studies: Teori dan Praktek. Yogyakarta: Bentang.

[6] BKSTI, (2017).BKSTI ub.ac.id /wpcontent/upload/2017/10/keynote Speker
Drajad Irianto.pdf.

[7] Bourdieu, Pierre. (1990). (Habitus X Modal) + Ranah $=$ Praktik : Pengantar Paling Komprehensif kepada Pemikiran Bourdie. Bandung: Jalasutra. Sumber terjemahan An Introduktion to the work of Pierre Bourdie: The Practice Theory. Editor Richard Harker. 1990. The Macmillan Press Ltd: London.

[8] Collier, Mary Jane, (1994), “Cultural Identity and Intercultural Communication", dalam Samovar, Larry A. dan Porter, Ricard E. (eds), Intercultural Communication: A Reader, Berlmont: Wadsworth.

[9] Dharmika, Ida Bagus, Gede Yoga Kharisma Pradana, Ni Made Ruastiti. (2020). Forest Conservation With The Basis Of Customary Village and Religion Rules in Bali. International Journal of Advanced Science and Technology, Vol. 29(8): pp. 571-579.

[10] Dharmika, Ida Bagus, Gede Yoga Kharisma Pradana. (2020). The Meaning of The Sutri Dance in Dewa Yadnya in Era to The Digital Era to The People of Pakraman Lebih Village, Gianyar Bali. International Journal of Advanced Science and Technology, Vol.14(5): pp. 647-665.

[11] Fang, Fan, Shuyi Zhang, Tariq Elyas. (2020). Role of Prior Intercultural Learning in Chinese University Student's Cross Cultural Adaptation. Pertanika Journal of Social Science and Hummaniora, Vol. 28(3): pp. 1599-1619.

[12] Giddens, A. (2003). The Constitution of So-ciety : Teori Strukturasi untuk Analisis Sosial (D. A. L. Sujono, Trans.). Pasuruan: Penerbit Pedati.

[13] Jaeni. (2012). Komunikasi Estetik: Menggagas Kajian Seni dari Peristiwa Komunikasi Pertunjukan. Bogor: IPB Press.

[14] Luan Ng, Miew, Yuen Beng Lee. (2020). Chinese Cultural Preservation, Identity and Community : Examining The Roles of Sin 
Chew Daily in Bridging Chinese Education, Cultural and Religious Rights of The Chinese Community in Malaysia. Pertanika Journal of Social Science and Hummaniora, Vol. 28(2): pp. 1335-1355.

[15] Mantra, Ida Bagus. (1996). Landasan Kebudayaan Bali. Denpasar: Yayasan Dharma Sastra.

[16] Martono, Nanang. (2012). Sosiologi perubahan sosial: perspektif klasik, modern, postmodern, dan postkolonial. Jakarta: PT. Raja Grafindo Persada

[17] Muhammad, Isa Bala, Abubakar Danladi Isah, Mohammed Bala Banki, Ahmed Salawu. (2020). Toponym and Evocation of Cultural Landscape Heritage : A Case of an African Community. Pertanika Journal of Social Science and Hummaniora, Vol. 28(3): pp. 2427-2440.

[18] Mulyana, Rohmat. (2004). Mengatikulasi Pendidikan Nilai. Bandung: Alfabeta.

[19] Nasseri, Edina Mohd, Tse Kian Neo, Vimala Perumal. (2020). Analysis of American Television and Its Impact on The Cultural Perception on Malaysian Youth. Pertanika Journal of Social Science and Hummaniora, Vol. 28(3): pp. 2441-2463.

[20] Paneli, Dwi Wahyu Wirawan. (2017). Transformasi Pertunjukan Wayang Orang Komunitas Graha Seni Mustika Yuastina Surabaya; Journal of Art, Design, Art Education And Culture Studies (JADECS), Vol 2 No. 2 - Desember 2017.

[21] Pradana, Gede Yoga Kharisma Pradana. (2017). Filsafat Ilmu Pariwisata. Denpasar : STPBI.

[22] Pradana, Gede Yoga Kharisma, I Nyoman Suarka, Anak Agung Bagus Wirawan, I Nyoman Dhana. (2016). Religious Ideology of The Tradition of The Makotek in The Era of Globalization. Electronic Journal of Cultural Studies, Vol. 9(1): 6-10.

[23] Pradana, Gede Yoga Kharisma, I Wayan Pantiyasa. (2018). Makotek As Tourist Attraction in Munggu Village. The
Proceeding of $2^{\text {nd }}$ The International Conference on Tourism, Gastronomy and Tourist Destination (ICTGTD). Jakarta : Atlantis Press.

[24] Pradana, Gede Yoga Kharisma, Komang Shanty Muni Parwati. (2017). LocalWisdom-Based Spa Tourism in Ubud Village of Bali, Indonesia. Russian Journal of Agricultural and Socio-Economic Sciences, Vol. 8(68):188-196.

[25] Pradana, Gede Yoga Kharisma, Komang Trisna Pratiwi Arcana. (2020). Balinese Traditional Homestay in a Sustainable Tourism Entering Millennial Era. Journal of Xi'an University of Architecture \& Technology, Vol. 12, No. 3: pp. 4208-4217.

[26] Pradana, Gede Yoga Kharisma, Komang Trisna Pratiwi Arcana. (2021). Hasil Pengelolaan Homestay Bercorak Budaya Tradisional Bali Ditengah Pengaruh Perkembangan Trend Millennial di Sektor Pariwisata. Jurnal Ilmiah Hospitality Management, Vol. 11(1), pp. 1-12.

[27] Pradana, Gede Yoga Kharisma. (2012). Diskursus Fenomena Hamil di Luar Nikah dalam Pertunjukan Wayang Joblar. Online Journal of Cultural Studies, Vol. 1, No. 2, pp. 11-27.

[28] Pradana, Gede Yoga Kharisma. (2017). Deconstruction Powers of Relations Behind The Shadow Puppet Performance For Tourism in Ubud Village, Bali. The International Proceeding of Building Collaboration and Networking in Globalized World, Denpasar : UNUD Press.

[29] Pradana, Gede Yoga Kharisma. (2018). Implications of Commodified Parwa Shadow Puppet Performance For Tourism in Ubud, Bali. Journal of Business on Hospitality and Tourism, Vol. 4, No. 1: pp. 70-79.

DOI: http://dx.doi.org/10.22334/jbhost.v4i1.103. g111. 
[30] Pradana, Gede Yoga Kharisma. (2018). Innovation in Cenk Blonk Performance : A Strategy of Empowering Local Language Through Balinese Shadow Puppet. The Proceeding of The International Conference on Local Language, Denpasar : UNUD Press.

[31] Pradana, Gede Yoga Kharisma. (2018). The Meaning of Makotek Tradition at The Munggu Village on The Global Era. The Proceeding of The International Bali Hinduism, Tradition and Intereligious Studies. Denpasar : UNHI Press.

[32] Pradana, Gede Yoga Kharisma. (2019). Sosiologi Pariwisata. Denpasar : STPBI Press.

[33] Pradana, Gede Yoga Kharisma. (2020). Corona in Pupuh Ginada Dasar : A Cultural Response to Crisis Situations Due To Corona Virus Pandemic. The Proceeding of The International Conference on Climate Change : Climate Actions Toward Sustainable Development Goals (MDGs). Surakarta : UNS.

[34] Rai S, I Wayan, Made Gde Sadguna Indra, I Gde Agus Sadguna Jaya, Gede Yoga Kharisma Pradana [2019]. Tifa From The Land Of Papua : Text And Context. ASIA LIFE SCIENCES The Asian International Journal of Life Sciences. Vol. 28(2), pp. 335-354. Phillippines : Rushing Water Publishers Ltd.

[35] Ristekdikti. (2018). Mempersiapkan SDM Indonesia di Era Industri 4.0 (Bahan Presentasi). Jakarta: Kementerian Riset, Teknologi dan Pendidikan Tinggi 2018; http://sdgcenter.unpad.ac.id/wp-

content/uploads/2018/09/ Kemenristek dikti-Mempersiapkan-SDM-Indonesia-di-

Era-Industri-4.0.pdf

[36] Robertson, R. (1992). Globalization Social Theory and Global Culture. Sage. London..

[37] Ruastiti, Ni Made, Gede Yoga Kharisma Pradana, I Gusti Ketut Purnaya, Komang
Shanty Muni Parwati. (2018). The Royal Dinner Party Puri Anyar Kerambitan Tabanan : A Sustainable Cultural Tourism Attraction Based on Local Community. The Proceeding of The $1^{\text {st }}$ International Conference on Social Science, Education and Humanities, Vol. 1, No. 226, pp. 14481459. https://doi.org/10.2991/icss$\underline{18.2018 .305 .}$.

[38] Ruastiti, Ni Made, Gede Yoga Kharisma Pradana. [2020]. The Ideology Behind Sesandaran Dance Show in Bali. Journal Sociology Social Anthropology. Vol. 11(2), pp. 78-85. India: Kamla-Raj Enterprises.

[39] Ruastiti, Ni Made. (2010). Seni Pertunjukan Pariwisata Bali Kemasan Baru Dalam Pespektif Kajian Budaya. Yogyakarta : Kanisius.

[40] Ruastiti, Ni Made. (2020b). Membangun Talenta Generasi Melenial Korban Napza (Makalah).

[41] Ruastiti, Ni Made. [2005]. Seni Pertunjukan Bali Dalam Kemasan Pariwisata. Denpasar: Bali Mangsi.

[42] Ruastiti, Ni Made. [2019a]. Deconstructing Ideologies Behind Rodat Dance in Kepaon Village, Bali, Indonesia in The Global Era. ASIA LIFE SCIENCES The Asian International Journal of Life Sciences. 28(1) pp. 17-29. Philipine: Rushing Water Publisher Ltd.

[43] Ruastiti, Ni Made. [2020]. Pengetahuan Pariwisata Bali. Papua: ASENI.

[44] Ruastiti, Ni Made. I Komang Sudirga, I Gede Yudarta. [2019]. Education Values in Wayang Wong Innovative Arts 'Cupu Manik Astagina'. Journal of Arts \& Humanities. 8(09) pp.87-100. United States: the LAR Center Press, OR, USA.

[45] Ruastiti, Ni Made. I Komang Sudirga, I Gede Yudarta. [2020]. Aesthetic Performance of Wayang Wong Millennial. International Journal of Innovation, Creativity and Change. 13(7) pp. 678-692. 
United Kingdom: Primrose Hall Publishing Group.

[46] Ruastiti, Ni Made. I Komang Sudirga, I Gede Yudarta. [2020a]. Model of Innovative Wayang Wong for Millenial Generation to Meet 4.0 Industrial Revolution Era in Bali. Journal of Environmental Treatment Techniques. 3 (8) 999-1004. United Arab Emirates: Dorma Journal.

[47] Ruastiti, Ni Made. I Komang Sudirga, I Gede Yudarta. [2020b]. The Wayang Wong Millennial Performance Art Model as a New Tourist Attraction in Bali. International Journal of Innovation, Creativity and Change. Vol. 14 (5). P.666683. United Kingdom: Primrose Hall Publishing Group

[48] Schaefer, Charles E., ed. (2003). Prescriptive play therapy. In Foundations of play therapy.306-20.

[49] Selian, Sri Nurhayati, Fonny Dameaty Hutagalung, Noor Aishah Rosli. (2020). Academic Stress, Coping and Social Cultural Adaptation of Psychological Well Being among Indonesian Postgraduate Students. Pertanika Journal of Social Science and Hummaniora, Vol. 28(4): pp. 2505-2527.

[50] Soedarsono. (2000). Masa Gemilang dan Memudar: Wayang Wong Gaya Yogyakarta. Yogyakarta : Tarawang

[51] Solichin. (2011). Falsafah Wayang, Intagible Heritage Of Humanity, Jakarta; Yayasan Senawangi

[52] Swandi, I Wayan, Arya Pageh Wibawa, Gede Yoga Kharisma Pradana, I Nyoman Suarka. (2020). The Digital Comic Tantri Kamandaka : A Discovery For National Character Education. International Journal of Innovation, Creativity and Change, Vol. 13(3): pp.718-732.

[53] Tejayadi, Putu Windhu, I Nengah Laba, Gede Yoga Kharisma Pradana. (2019). The Effect of Organizational Culture on
Employee Satisfaction in Mercure Resort Sanur Bali Hotel. The International Journal of Green Tourism Research and Applications, Vol. 1, No. 1, pp. 63-72.

[54] Yasasusastra, J. Syahban. (2011). Mengenal Tokoh Pewayangan Biografi, Bentuk dan Perwatakannya. Yogyakarta : Pustaka Mahardika.

[55] Zhang, Juan, John Walsh. (2020). Tourist Experience, Tourist Motivation and Destination Loyalty for Historic and Cultural Tourists. Pertanika Journal of Social Science and Hummaniora, Vol. 28(4): pp. 3277-3296. 